\title{
Monitoring the Specie Melolontha Melolontha L. in the Nursery of Lunca Bradului Forestry Department
}

\author{
Ion OLTEAN ${ }^{11}$, Alexandru BEXA, Teodora FLORIAN ${ }^{1}$, Mircea Ioan VARGA ${ }^{1)}$ \\ 1) Department of Environment and Plant Protection. University of Agricultural Sciences and Veterinary \\ Medicine Cluj-Napoca, Romania \\ ${ }^{*}$ Corresponding author, e-mail: varga_mrc@yahoo.com
}

Bulletin UASVM Horticulture 72(1) / 2015

Print ISSN 1843-5254, Electronic ISSN 1843-5394

Doi:10.15835/buasvmcn-hort:10603

\begin{abstract}
The European cockchafer Melolontha melolontha L. is one of the main pests of forestry species. The adult of this species cause defoliation in deciduous forest stands, while the larvae attack in the soil, consuming seeds or roots. In forest nurseries and also in young forest plantations that belong to Lunca Bradului Forestry Department, attacks produced by the European cockchafer Melolontha melolontha L. are reported every year. Infested areas and especially the population density are very different from one year to another and also between various location, these being determined by climate conditions, but especially by the prevention and combating methods applied in each forest nursery. In Lunca Bradului Forestry Department, annually population density evaluation was carried out by soil surveys.
\end{abstract}

Keywords: European cockchafer, larvae, monitoring, population density.

\section{INTRODUCTION}

The European cockchafer Melolontha melolontha L. is one of the main pests of forestry species. The adult of this species cause defoliation in deciduous forest stands, while the larvae attack in the soil, consuming seeds or roots (Głowacka Barbara and Alicja Sierpińska, 2012). The larvae cause the greatest damage, both in forest nurseries and young plantations. In tree nurseries, the economic damage produced by these pests is very severe, because the value of planting material is very high (Holonec et. al., 2007a, 2007b, 2007c, Oltean, 2005; Varga et al., 2014).

\section{AIMS AND OBJECTIVES}

The aim of the study was the monitoring of the specie Melolontha melolontha $\mathrm{L}$. in the nurseries of Lunca Bradului Forestry Department to establish the numeric population density of larvae in order to assess the attack degree.

\section{MATERIALS AND METHODS}

The detection of infestations produced by Melolontha melolontha L. was conducted in August 2014 by making the surveys in all the forest nurseries where the presence of larvae (grubs), pupae or adult beetles have been identified. The survey pits had $1 \times 1 \times 1 \mathrm{~m}$ dimensions. The collected larvae were separated by age, at each survey, establishing the average number of larvae by age groups, existing on $\mathrm{m} 2$. At I and II instars larvae was applied the coefficient of equivalence in third instar larvae. Assessment of attack intensity was made by active larvae population density equivalent to third instar larvae found on $\mathrm{m} 2$. All the third instar larvae was calculated using the formula:L1/5 + L2/3 + L3.

Data interpretation has been made according to Tab. 1. 
Tab. 1. The degree of infestation produced by Melolontha melolontha $\mathrm{L}$.

\begin{tabular}{ccccc}
\hline The average number of $M$. & \multicolumn{3}{c}{ The degree of damage(infestation) } \\
\cline { 2 - 5 } $\begin{array}{c}\text { melolontha larvae per } \mathrm{m}^{2} \text { and } \\
\text { instars }\end{array}$ & Very Strong & Strong & Medium & Weak \\
\cline { 2 - 5 } & $91-100 \%$ & $51-90 \%$ & $26-50 \%$ & $1-25 \%$ \\
\hline Third instar & More than1 & $0.51-1$ & $0.26-0.5$ & up to the value 0.25 \\
\hline Second instar & More than 3 & $1.51-3$ & $0.76-1.5$ & up to the value 0.75 \\
\hline First instar & More than 5 & $2.51-5$ & $1.26-2.5$ & up to the value 1.25 \\
\hline
\end{tabular}

\section{RESULTS AND DISCUSSION}

In the forestry nurseries of Lunca Bradului in 2009 the attack produced by the larvae of the European cockchafer was reported on 88 ha: 25 ha weak, 24 ha with medium attack and 39 ha with strong attack in the forest nursery. In the young forest stands the attack was reported on 6.7 ha, surface belonging to the National Forest Administration and on 8.5 ha of stands administrated by private management (situated in Production Unit.II Ilişoara and P.U. V Zebrac).

In 2010 the attack produced by the larvae was reported on 60 ha ( 40 ha weak, 6 ha with medium attack and 14 ha with strong attack), in the forest nursery of Jârca and Cucuța. In the young forest stands the attack was reported on 26.1 ha belonging to the National Forest Administration and on 2.3 ha of private administrated stands. In 2011 the attack produced was reported on 33.5 ha (4 ha with medium attack and 29.5 with strong attack) in the nursery of Ketag I, Jârca, Cucuța. In the young forest stands the attack was reported on 6.3 ha, surface belonging to the National Forest Administration (in P.U. III Neagra, P.U. V Zebrac şi P.U. VI Gudea) and on 3.5 ha of private administrated stands (situated in P.U. Ilva). In 2012 the attack produced is reported on 43.5 ha (33 ha with weak attack, 4.5 ha with medium and 6 ha with strong attack) in the forest nursery and in the the young forest stands the attack was reported on 16.8 ha. In the year 2013 the attack was noted on 58 ha from which 14 ha with weak attack, 16 ha medium and on 28 ha the attack was strong.

Our findings are according to the study made by Švestka (2006) in Czech Republic who found that M. melolontha attacked 500 ha (year 2005) in the Forest district Mikulov and 80 ha in Forest district Lipník (year 2002-2003). This author saw an increased incidence and mass outbreaks of $M$. melolontha on surfaces of 10000 ha of forest stands. Also a study performed in Poland, in the years 1995, 1999, 2003, 2007 and 2011 showed that succeeding swarmings of Melolontha melolontha and M. hippocastani took place in forests on 15, 26, 46, 99 and 120 thousand hectares (Głowacka and Sierpińska, 2012).

\section{CONCLUSION}

The larvae of European cockchafer are reported in all forestry nurseries and the level of infestation shows oscillations, from a nursery to another and from one year to another.

\section{REFERENCES}

1. Głowacka B, Sierpińska A (2012). Control of adult cockchafers Melolontha spp., with Mospilan 20 SP. Folia Forestalia Polonica, series A 54 (2):109-115.

2. Holonec L, Cristina M, Mazăre G, Deac C, Ceuca V (2007b). Place and role of preventive measures in the context of integrated protection of forest ecosystems. Plant Protection Magazine 65:62-66.

3. Holonec L, Florian V, Oroian I, Todea A, Vîlcan A (2007c). Economic aspects regarding control measures in the nurseries and in the forest stands. Plant Protection Magazine 66:41-44.

4. Holonec L, Florian V, Oroian I, Todea A, Viman O (2007a). Aspects regarding phytosanitary status of nurseries and protective and curative measures regarding forest protection.Plant Protection Magazine 65:11-16.

5. Oltean I (2005). Entomologie specială - Dăunătorii pădurilor. Editura AcademicPres. 266p.

6. Švestka M (2006). Distribution of tribes of cockchafers of the genus Melolontha in forests of the Czech Republic and the dependence of their swarming on temperature. J. FOR. SCI., 52, 2006 (11): 520-530.

7. Varga MI, Oltean I, Muntean V, Florian T, Mândru M (2014). Monitoring the species Melolontha melolontha L. in the nursery of Gurghiu Forestry High School. Bulletin UASVM Horticulture 71(1):128-129. 